\title{
IbM KELOMPOK ORGANISASI MAHASISWA UNIVERSITAS LANCANG KUNING DALAM PENGGUNAAN SOFTWARE DESIGN GRAFIS
}

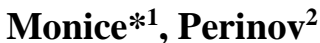 \\ ${ }^{1,2}$ Prodi Teknik Elektro, Fakultas Teknik, Universitas Lancang Kuning \\ *E-mail: monice@unilak.ac.id
}

\begin{abstract}
Nowadays, in the younger generation, students in particular, there is less and less motivation for entrepreneurship. This is also because many do not have the skills that can be used to support it. Student organizations are a representative of a part of younger generation who have problems of their own. Student organizations have many activities, which requires skill and expertise in the field of graphic design. This activity, Science and Technology for Community is a positive step to expand the horizons and motivate the younger generation, especially students through student organizations in order to foster an entrepreneurial spirit and the spirit to always learn new things and keep up with technology. The methods which are used, such as workshop or training in using graphic design software and discussion to open up horizons for entrepreneurship. Material which is provided, include handout of Basic Training for Adobe Indesign for making posters, brochures and banners, as well as ideas of business opportunities that can be developed by students or student organizations. Conclusions, outcomes achieved are the participants have basic skills and knowledge in using the software Adobe Indesign for making posters, and the emergence of ideas in entrepreneurship in the field of graphic design from the participants.
\end{abstract}

Keywords-Graphic Design, Entrepreneurship

\begin{abstract}
Abstrak
Generasi muda pada umumnya, mahasiswa pada khususnya tidak banyak yang memiliki motivasi untuk berwirausaha. Ini dikarenakan banyak yang tidak memiliki keterampilan yang bisa digunakan untuk mendukungnya. Organisasi-organisasi mahasiswa di kampus merupakan cerminan perwakilan dari sebagian generasi muda yang memiliki permasalahan-permasalahan tersendiri. Organisasi-organisasi mahasiswa memiliki kegiatan-kegiatan yang sangat bervariasi, yang membutuhkan keterampilan dan keahlian di bidang desain grafis.Kegiatan Iptek bagi Masyarakat ini merupakan langkah positif yang dapat membuka wawasan dan memotivasi generasi muda, melalui organisasi mahasiswa, untuk menumbuhkan jiwa wirausaha, serta semangat untuk selalu mempelajari hal-hal baru dan mengikuti perkembangan teknologi. Metode yang digunakan adalah berupa workshop atau pelatihan dalam menggunakan software desain grafis dan diskusi untuk membuka wawasan untuk berwirausaha. Materi yang diberikan berupa handout Pelatihan Dasar Adobe Indesign untuk pembuatan poster, brosure maupun spanduk, serta ide-ide peluang usaha yang dapat dikembangkan oleh mahasiswa ataupun organisasi mahasiswa. Kesimpulan, luaran yang dicapai adalah peserta mempunyai keterampilan dan pengetahuan dasar dalam menggunakan software Adobe Indesign untuk pembuatan poster, serta munculnya ide-ide dalam berwirausaha dalam bidang desain grafis dari peserta.
\end{abstract}

Kata kunci-Desain Grafis, Wirausaha

\section{PENDAHULUAN}

Dewasa ini generasi muda pada umumnya, mahasiswa pada khususnya belum banyak memiliki motivasi untuk berwirausaha, disamping itu juga dikarenakan banyak yang tidak memiliki keterampilan yang bisa digunakan untuk mendukungnya. 
Peningkatan sumber daya manusia merupakan hal yang sangat dibutuhkan untuk meningkatkan produktifitas. Berkenaan dengan hal itu kami sebagai bagian dari tenaga pendidik sehubungan dengan kegiatan Iptek bagi Masyarakat akan mengadakan pelatihan penggunaan software disain grafis untuk generasi muda, khususnya mahasiswa melalui organisasi - organisasi mahasiswa yang ada dilingkungan kampus Universitas Lancang Kuning.

Organisasi-organisasi mahasiswa di kampus merupakan cerminan perwakilan dari sebagian generasi muda yang memiliki permasalahan-permasalahan tersendiri. Organisasiorganisasi mahasiswa memiliki kegiatan-kegiatan yang sangat bervariasi, yang membutuhkan keterampilan dan keahlian di bidang disain grafis agar dapat mandiri dan membuka wawasan akan peluang-peluang berwira usaha di bidang tersebut.

\section{Solusi}

Kegiatan Iptek bagi Masyarakat ini merupakan langkah positif yang dapat membuka wawasan dan memotivasi generasi muda, khususnya mahasiswa melalui organisasi-organisasi mahasiswa dalam upaya menciptakan peluang usaha dan menumbuhkan jiwa wirausaha, serta semangat untuk selalu mempelajari hal-hal baru dan mengikuti perkembangan teknologi.

Materi yang diberikan meliputi, pelatihan penggunaan software disain grafis, yaitu Adobe Indesign, untuk pembuatan poster, brosure maupun spanduk, serta ide - ide peluang usaha yang dapat dikembangkan oleh mahasiswa ataupun organisasi mahasiswa.

Selanjutnya peserta yang telah selesai mengikuti pelatihan dan telah memiliki keterampilan diharapkan akan terus ditumbuhkembangkan jiwa kewirausahaannya untuk membuka wawasan guna menciptakan peluang-peluang usaha baru dan dapat menularkan semangat kepada rekanrekannya.

\section{METODE}

Jenis kegiatan Iptek bagi Masyarakat ini adalah berupa pelatihan penggunaan software di bidang disain grafis, dengan memberikan hand out dan pelatihan penggunaan software secara langsung melalui praktek disain poster.

Lokasi pelaksanaan kegiatan Iptek bagi Masyarakat ini adalah di Laboratorium Komputer Teknik Elektro Fakultas Teknik Universitas Lancang Kuning.

Metode pelaksanaan kegiatan Iptek bagi Masyarakat ini meliputi beberapa metode, yakni:

1. Pemberian hand out dengan judul Modul Pelatihan Dasar Adobe Indesign, yang diringkas dari Gordon, Jonathan and Jansen, Cari. 2016.

Designing an Event Poster

Starting the Project

Creating a New Document Using Ruler and Smart Guides

Preferences

Organizing Design Elements inLayers

Adding Design Elements

Adding Shapes and LinesCreating Combined Shapes

Adding Color Gradients

Adding Images and Graphics Adding and Formatting Text

Submitting Your Poster

Submitting Proofs to Clients Submitting a PDF to the Printer

2. Pelatihan penggunaan software.

Penyuluhan atau diskusi untuk membuka wawasan untuk berwirausaha

a. Pelatihan penggunaan software secara langsung melalui praktek pembuatan poster, yang dilakukan di Laboratorium Komputer Teknik Elektro.

b. Mahasiswa langsung melakukan praktek dengan mengikuti petunjuk yang terdapat di dalam hand out yang diberikan.

c. Praktek dilakukan masing-masing mahasiswa, berbarengan dengan tanya jawab dan diskusi. 
DINAMISIA - Jurnal Pengabdian Kepada Masyarakat Vol. 2, No. 2 Desember 2018, Hal. 236-239

3. Penyuluhan atau diskusi untuk membuka wawasan untuk berwirausaha.

a. Diskusi mengenai kemungkinan-kemungkinan peluang usaha yang dapat dilakukan.

b. Memberikan ide-ide usaha yang dapat dilakukan mahasiswa ataupun organisasi mahasiswa guna mendorong semangat kewirausahaan

\section{HASIL DAN PEMBAHASAN}

Luaran yang dicapai dari kegiatan Iptek bagi Masyarakat ini adalah:

1. Peserta mempunyai keterampilan dan pengetahuan dasar dalam menggunakan software Adobe Indesign untuk pembuatan poster, brosure ataupun spanduk, dan juga mengetahui alternatif alternatif software open source (gratis dan legit) lain yang dapat digunakan dalam bidang disain grafis, seperti: gimp dan inkscape, yang dapat diperoleh secara gratis dengan mengunduhnya secara online.

2. Munculnya ide-ide dalam berwirausaha sebagai kegiatan diluar perkuliahan yang bermanfaat di bidang disain grafis, sebagai contoh:

a. Jasa disain poster kegiatan, brosur ataupun spanduk.

b. Jasa disain buku-buku tahunan untuk mahasiswa yang lulus atau wisuda.

c. Jasa disain majalah ataupun pamflet.

3. Munculnya semangat mahasiswa untuk mempelajari software sebagai modal untuk membuka usaha.

4. Kemandirian peserta dalam hal disain grafis untuk baik untuk kebutuhan pribadi ataupun kegiatan organisasi kemahasiswaan.

\section{KESIMPULAN}

Dari kegiatan Iptek bagi Masyarakat ini dapat diambil kesimpulan dan saran:

1. Peserta mampu mengikuti pelatihan dengan cukup baik, dan mampu untuk membuat poster sesuai dengan praktek yang dilakukan, tetapi masih memerlukan bimbingan karena Modul Pelatihan Dasar Adobe Indesign untuk pembuatan poster masih dalam bahasa inggris, dengan pertimbangan perintah-perintah dalam software juga berbahasa inggris yang malah akan cukup membingungkan apabila dialih bahasakan, namun peserta cukup terbantu karena tiap perintah disertai dengan petunjuk gambar yang cukup jelas.

2. Ide - ide wirausaha yang muncul cukup baik dan bisa langsung diaplikasikan dilingkungan kampus, namun butuh semangat dan kemauan peserta untuk berani membuat proposal dan menyerahkannya ke pihak-pihak yang diperkirakan membutuhkannya, sebagai contoh :

a. Program Studi - Program Studi yang ada di lingkungan Universitas Lancang Kuning, sebagai contoh : dalam pembuatan buku tahunan mahasiswa yang di wisuda, majalah jurnal, poster-poster dan spanduk kegiatan.

b. Fakultas - fakultas yang ada di lingkungan Universitas Lancang Kuning, dalam pembuatan buku - buku, majalah, ataupun kompilasi S.O.P yang ada yang dapat diberikan kepada dosen - dosen, ataupun tiap mahasiswa baru. juga poster-poster dan spanduk kegiatan.

c. Rektorat yang memiliki sangat banyak kegiatan.

\section{SARAN}

Dengan demikian saran yang dapat diberikan adalah apabila ada proposal yang masuk ke pihak - pihak tersebut di atas, akan sangat baik apabila kreativitas dari mahasiswa ini untuk difasilitasi, walaupun mungkin hasil di awal tidak sebaik professional, namun akan sangat memotivasi mahasiswa dalam melakukan kegiatan - kegiatan positif yang menghasilkan 
DINAMISIA - Jurnal Pengabdian Kepada Masyarakat Vol. 2, No. 2 Desember 2018, Hal. 236-239

\section{UCAPAN TERIMA KASIH}

Terimakasih kepada Ketua himpunan Teknik sipil dan Ketua Himpunan Teknik Elektro serta mahasiswa yang telah diutus dalam acara Iptek bagi Masyarakat kampus ini.

\section{DAFTAR PUSTAKA}

[1] Gordon, Jonathan and Jansen, Cari. 2016. Learn Adobe InDesign CC for Print and Digital Media Publication. Peachpit Press

[2] Anton, Kelly Kordes and Cruise, John. 2016. Adobe InDesign CC Classroom in a Book. Peachpit Press. 